\title{
USING INSTRUMENTAL ENRICHMENT ACTIVITIES IN IMPROVING READING COMPREHENSION SKILLS OF EFL PREPARATORY STAGE PUPILS AND THEIR ATTITUDES TOWARDS THE ENGLISH LANGUAGE Asmaa Abdel-Aziz Ismail Salem El-Abady
}

\begin{abstract}
This study aimed at investigating the effect of using activities based on instrumental enrichment (IE) on improving the reading comprehension skills of the first year preparatory stage pupils and their attitudes towards the English language. To achieve this aim, a quasi-experimental design was launched on sixty- six pupils from $\mathrm{El}$ Ashraf Co-educational School, Belqas, Dakahliya. A reading comprehension subskills questionnaire was developed by the researcher to determine the reading comprehension sub-skills necessary for the first year preparatory stage pupils. Criteria checklist was also developed by the researcher to select and evaluate the suitable reading passages, and activities for the study. In addition, a pre - post reading comprehension sub-skills test was developed by the researcher to assess pupils' levels on reading comprehension skills before and after receiving the activities based on IE. Also, an attitude scale was developed by the researcher to determine pupils' attitudes towards the English language before and after receiving the activities based on IE. The results revealed that the activities based on IE had a high effect on the experimental group. The experimental group outperformed the control group on the post- administration of the reading comprehension sub-skills test. Furthermore, the experimental group's attitude was substantially improved compared with the control group. These results also led to a number of recommendations that related to the importance of IE in teaching and learning the language.
\end{abstract}

Key Words: Instrumental Enrichment, Attitude Scale, Reading Comprehension Skills, Preparatory Stage, English Language. مستخلص الدراسة تعتبر مهارات الفهم القرائى من اهم المهارات التعلمية التى يكتسبها المتعلم من خلال العملية لما لها من مميزات متعدده، فالقراءة تساعد المتعلمين على تحسينافكارهم بوتوسيع على مداركهم. و قد اثبتت العديد من الدراسات

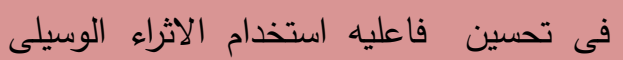
الحاليه مهارات الفهم القرائى. وتهدف الدراسة على الاثراء الوسيلى الى استخدام انشطه قائمه فى تحسين مهارات الفهم القرائى لدى طلبه الصف الاول الاعدادى وتحسين اتجاهاتهم الدراسة نحو اللغة الانجليزيه. و وقد تبنت التصميم شبه التجرببى باستخدام مجموعتين احداهما تجربية و الاخرى ضابطه، حيث تتلقى المقرره المدرسيه المجموعة التجربية الانشطة القائمه على الاثراء الوسيلى بجانب الانشطه

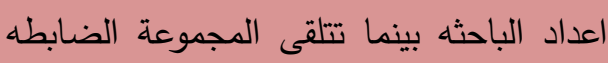
الدراسى المنهج الانشطه المقرة فقط فى اجريت وقد الخاص بالصف الأول الاعدادى مركز بلقاس فى فى مدرسة الاشراف المشتركه

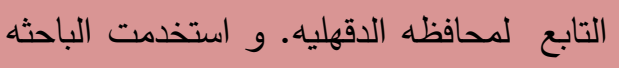
اللازمه استبيان لتحديد مهارات الفهم القرائى 


\begin{tabular}{|c|c|}
\hline 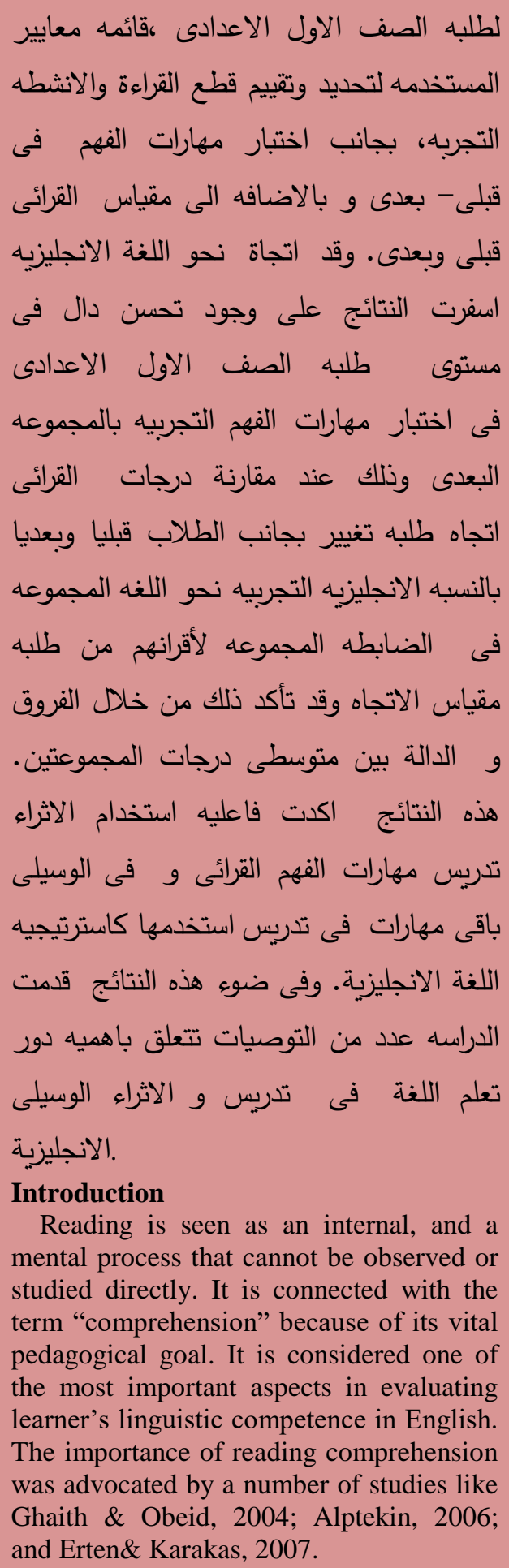 & $\begin{array}{l}\text { has indicated that linguistic competence in } \\
\text { the language depends not only on } \\
\text { intellectual capacity but also on the } \\
\text { learners' attitudes towards the language. } \\
\text { Number of studies has investigated the } \\
\text { effect of attitude on the English language } \\
\text { such as Alhmali 2007; Ghazali et al, 2009; } \\
\text { and Fakeye, 2010. Rani (2000) noted that } \\
\text { learners' attitudes towards learning may } \\
\text { improve or change by suggesting new } \\
\text { programs, and utilizing new approaches in } \\
\text { teaching. } \\
\text { Feuerstein's Instrumental Enrichment } \\
\text { program (IE) is considered an effective } \\
\text { teaching program which provides learners } \\
\text { with techniques, activities, and skills } \\
\text { through Mediated Learning Experience } \\
\text { (MLE). By MLE, learners learn "how to } \\
\text { learn" which can lead to increase the } \\
\text { academic performance, and make a } \\
\text { positive attitude towards English. IE has } \\
\text { been adapted in teaching and many studies } \\
\text { uphold its positive effect on teaching such } \\
\text { as Getz, 1992;El-Banna, 2000; Shoaer, } \\
\text { 2003; Qorany, 2005; El-Se'ady, 2008; } \\
\text { Hala, 2010;Abeid ,2010; and AL-Nifayee, } \\
\text { 2010. } \\
\text { This study was set up to investigate the } \\
\text { effect of using activities based on IE on } \\
\text { improving the first year preparatory stage } \\
\text { pupils' reading comprehension skills and } \\
\text { their attitudes towards English. } \\
\text { Review of related studies } \\
\text { Brain (1982) studied the effect of an } \\
\text { expanded form of IE delivery on the } \\
\text { reading achievement, reasoning abilities, } \\
\text { and task orientation of a group of sixth } \\
\text { grade underachievers in Westchester } \\
\text { County in New York. Major findings } \\
\text { revealed that: (1) no significant differences } \\
\text { between E- and C-groups' gain scores in } \\
\text { reasoning abilities; (2) between-group } \\
\text { analyses of Total Reading gains showed E- } \\
\text { and the teacher subjectivity in ratings. } \\
\text { ofiontation data were discounted because }\end{array}$ \\
\hline
\end{tabular}


Getz (1992) developed a block course incorporating study skills, English, reading, and critical thinking to meet the academic needs of forty students from Pikes Peak Community College Colorado. The results showed an improvement in reading and English. The results also indicated the possibility to integrate some of the Feuerstein ideas into an existing developmental studies course curriculum.

William and Kopp (1994) measured the effect of IE on the reading comprehension. One hundred students from all sixth grade classes assigned to experimental groups that received three forty-five-minute sessions of IE per week, taken from the regular curriculum, and control groups that received the regular curriculum. The Stanford Achievement Test for Reading (SAT-R) was administered to the two groups at the beginning of the study and at the end of every year of the program. The results indicated that the total SAT-R mean scores showed an increasing gap between the groups in favor of IE group.

AL-Nifayee (2010) investigated the effectiveness of the IE Approach on enhancing the reading comprehension skills of the preparatory stage pupils with English Language learning difficulties. The researcher adapted materials by using the IE. A standardized intelligence test, and a reading comprehension test were used as instruments to collect the data. The results revealed that there was a statistically significant difference between the mean scores of the experimental and the controlgroup on the post- application of the reading comprehension test in favor of the experimental group.

\section{Statement of the Problem}

Based on the results of the pilot study, and the literature review, the problem of the current study can be stated as follows:

The EFL first year preparatory stage pupils face difficulty in their reading comprehension skills, and have a negative attitude towards English. This difficulty and their negative attitudes could be due to the lack of using the reading activities, and the stereotypes of teaching. Thus, there was a need for using activities based on IEto improve the reading comprehension skills of EFL first year preparatory stage pupils and their attitudes towards English.

\section{Questions of the Study:}

a) What are the reading comprehension sub- skills necessary for the first year preparatory stage pupils?

b) To what extent will activities based on IE enhance the reading comprehension sub-skills of the first year preparatory stage pupils?

c) To what extent will activities based on IE improve the attitudes of the first year preparatory stage pupils towards the English language?

\section{Purpose of the Study}

The current study aimed at:

1. Identifying the reading comprehension sub - skills necessary for the first year preparatory stage pupils.

2. Designing activities based on IE to enhance reading comprehension skills and change the negative attitudes towards the English language.

3. Measuring the effectiveness of the activities based on IE on improving reading comprehension skills and attitudes towards the English language of the first year preparatory stage pupils.

4. Significance of the Study

It is hoped that the present study will contribute to:

1. Direct the attention of EFL teachers and curriculum planners towards the utilizing of IE in improving the reading comprehension sub- skills and the attitudes towards English.

2. Enrich the literature concerning with the effect of the IE on teaching. 
3. Evoke pupils' interests towards reading and English.

4. Pave the way for other researchers to investigate the effect of IE on developing other language skills.

Delimitations of the Study

The current study was delimited to the following:

1. A sample from the first year preparatory stage pupils.

2. Activities based on IE designed by the researcher.

3. Nine reading comprehension subskills like Scanning, Skimming, Analyzing of written information, Identifying referent for pronouns, Identifying of word meaning, determining the truth of the sentence, Sequencing, Making an Inference, andMaking Comparisons.

4. Number of IE such as Illustration, Comparing, Categorization, Instructions, Family Relations, Orientation in Space I, Orientation in Space II, Analytic perceptions, Syllogisms, Temporal Relations, The Numerical Progressions, Transitive Relations, Representational Stencil Design.

\section{Hypotheses of the study}

1. There is no statistically significant difference between the mean scores of the experimental group and the control group on the pre - administration of the reading comprehension sub-skills tst.

2. There is a statistically significant difference at the 0.05 level between the mean scores of the experimental group and the control group on the postadministration of the reading comprehension sub- skills test in fvor of the experimental one.
3. There is a statistically significant difference at the 0.05 level between the mean scores of the experimental group on the pre administration and on the post administration of the reading comprehension sub- skills test in favor of the post-administration.

4. There is no statistically significant difference between the mean scores of the experimental group and control group on the pre-administration of the attitude scale.

5. There is a statistically significant difference at the 0.05 level between the mean scores of the experimental group and the control group on the post administration of the attitude scale in favor of the experimental one.

6. There is a statistically significant difference at the 0.05 level between the mean scores of the experimental group on the preand post-administration of the attitude scale in favor of the postadministration.

\section{Methodology \\ Design of the study}

The study adopted a quasi - experimental design which involved two groups; an experimental group and a control group. The study was carried out at El- Ashraf Co-educational School, Belqas, Dakahliya. It was implemented in the first semester of the academic year 2014-2015.

\section{Participants}

The participants of this study were selected from the first year Preparatory stage in El Ashraf Co-educational School, Belqas, Dakahlya. Two classes were selected and assigned as an experimental group and a control group. There were thirty-three pupils in each class. The experimental group received activities based on IE, which were designed by the 
researcher, and textbook activities suggested by the Ministry of Education. On the other hand, the control group received only the textbook activities suggested by the Ministry of Education.

\section{Instruments of the study}

The researcher developed the following instruments:

1. A Reading Comprehension SubSkills Questionnaire to determine the reading comprehension skills necessary for the first year preparatory stage pupils.

2. Criteria Checklist for selecting, and evaluating the reading comprehension activities.

3. Activities based on IE to improve the reading comprehension skills of the first year preparatory stage pupils and their attitudes towards the language.

4. A pre/ post Attitude Scale to determine pupils' attitudes towards English.

5. A pre/ post Reading Comprehension Sub -Skills Test to assess pupils' reading comprehension skills levels.

\section{Procedures of the study:}

The study was carried out in the followingsteps:

1. Reviewing the literature related to the reading comprehension subskills, the attitudes towards the language, and the effect of IE on teaching.

2. Designing a reading comprehension sub- skills questionnaire to determine the reading comprehension skills that are necessary for the first year preparatory stage pupils.

3. Designing activities based on (IE).

4. Designing a criteria checklist to select, and evaluate the reading comprehension activities.
5. Designing a reading comprehension sub- skills test to apply it as a pre and a post- test, and assess pupils' reading comprehension skills levels.

6. Designing an attitude scale to identify pupils' attitude towards English, and apply it before and after the experiment.

7. Submitting the reading comprehension sub- skills test and the attitude scale to the jurors for validity.

8. Getting a permission to conduct the study from the school principal.

9. Conducting a pilot study on thirty- three pupils who did not participate in the study to ensure the reliability of the instruments.

10. Pre-administering of the reading comprehension sub- skills test on the two groups.

11. Pre-administering of the attitude scale on the two groups.

12. Implementing the activities based on IE on the experimental group.

13. Post - administering of the reading comprehension sub- skills test on the two groups.

14. Post-administering of the attitude scale on the two groups.

15. Comparing the results of the two groups.

16. Analyzing the data statistically by using the appropriate statistical methods.

17. Discussing the results and providing conclusions and recommendations.

18. Writing the thesis according to the guidelines presented in the guide for writing theses and dissertations at Mansoura University.

Definition of Terms

1-Instrumental Enrichment: 
Ben-Hur (2000) defined IE as a classroom curriculum designed to enhance the functions necessary for academic learning and achievement.

IE was defined operationally as a free content that consists of a collection of reading activities and techniques in which the mediator used to enhance pupils' reading comprehension sub- skills and their attitudes towards the English language.

\section{2-Reading Comprehension:}

In the opinion of Al-Ghoul (2009), reading comprehension was an understanding and extracting meanings from the reading material.

Reading comprehension was defined operationally as the dynamic procedures that establish the perception of a written material through a number of complex processes involving an interaction between the pupil, and the activity.

Table (1) t-test comparing the two group's mean scores on each reading comprehension sub- skill and their total mean scores overall reading comprehension sub- skills on the preadministration of the test

\begin{tabular}{|c|c|c|c|c|c|c|c|c|}
\hline $\begin{array}{l}\text { The reading } \\
\text { comprehension sub-skills }\end{array}$ & Group & $\mathbf{N}$ & Mean & SD & $\mathbf{T}$ & $\begin{array}{c}\mathrm{DF}(\mathbf{n} 1+\mathbf{n} 2- \\
\text { 2) }\end{array}$ & $\begin{array}{c}\text { Level } \\
\text { of } \\
\text { Sig. }\end{array}$ & $\begin{array}{c}\text { Sig. } \\
(2- \\
\text { tailed })\end{array}$ \\
\hline \multirow{2}{*}{ Scanning } & Control & 33 & 3.27 & 3.175 & \multirow{2}{*}{0.27} & & \multirow{2}{*}{0.8} & \multirow{20}{*}{ tallea) } \\
\hline & Exp. & 33 & 3.09 & 2.3098 & & & & \\
\hline \multirow{2}{*}{ Skimming } & Control & 33 & 1.82 & 1.9598 & \multirow{2}{*}{0.63} & & \multirow{2}{*}{0.5} & \\
\hline & Exp. & 33 & 2.12 & 1.933 & & & & \\
\hline \multirow{2}{*}{$\begin{array}{l}\text { Analyzing the written } \\
\text { information }\end{array}$} & Control & 33 & 1.9697 & 1.7497 & \multirow{2}{*}{0.72} & & \multirow{2}{*}{0.5} & \\
\hline & Exp. & 33 & 2.273 & 1.6587 & & & & \\
\hline \multirow{2}{*}{ Identifying of word meaning } & Control & 33 & 2.12 & 1.691 & \multirow{2}{*}{1.02} & & \multirow{2}{*}{0.3} & \\
\hline & Exp. & 33 & 2.576 & 1.9126 & & & & \\
\hline \multirow{2}{*}{ Making inference } & Control & 33 & 0.9 & 1.33 & \multirow{2}{*}{0.2} & & \multirow{2}{*}{0.8} & \\
\hline & Exp. & 33 & 0.85 & 1.121 & & 64 & & \\
\hline \multirow{2}{*}{$\begin{array}{l}\text { Identifying referent for } \\
\text { pronouns }\end{array}$} & Control & 33 & 0.36 & 0.699 & \multirow{2}{*}{0.4} & 04 & \multirow{2}{*}{0.7} & \\
\hline & Exp. & 33 & 0.3 & 0.68 & & & & \\
\hline \multirow{2}{*}{$\begin{array}{l}\text { Determining the truth of } \\
\text { statement }\end{array}$} & Control & 33 & 1.27 & 1.076 & \multirow{2}{*}{0.34} & & \multirow{2}{*}{0.7} & \\
\hline & Exp. & 33 & 1.36 & 1.07 & & & & \\
\hline \multirow{2}{*}{ making comparison } & Control & 33 & 0.3 & 0.47 & \multirow{2}{*}{0.00} & & \multirow{2}{*}{1.0} & \\
\hline & Exp. & 33 & 0.3 & 0.47 & & & & \\
\hline \multirow[t]{2}{*}{ Sequencing } & Control & 33 & 0.39 & 0.61 & \multirow{2}{*}{0.66} & & \multirow{2}{*}{0.5} & \\
\hline & Exp. & 33 & 0.3 & 0.51 & & & & \\
\hline \multirow{2}{*}{$\begin{array}{l}\text { Overall reading } \\
\text { comprehension sub- skills }\end{array}$} & Control & 33 & 12.42 & 11.53 & \multirow{2}{*}{0.28} & & \multirow{2}{*}{0.8} & \\
\hline & Exp. & 33 & 13.18 & 10.448 & & & & \\
\hline
\end{tabular}

Table (1) shows that the $\mathrm{t}-$ values which range between $(0.00)$ and $(0.66)$, are not statistically significant. This indicates that there is no statistically significant

\section{3- Attitude}

Al-Noursi (2013) also illustrated the attitude concept as the learners' perceptions, understandings, beliefs, or experiences of learning English as a foreign language as assessed by a specially designed questionnaire.

Attitude was defined operationally as a pupil's trend or a way of thinking to react positively or negatively towards the language.

\section{Results and statistical analysis:}

To test the first hypothesis "There is no a statistically significant difference between the mean scores of the experimental group and the control group on the pre-administration of the reading comprehension sub- skills test", the independent sample $t$ - test was used for comparing the two groups on the preadministration of the reading comprehension sub- skills test. 
low level on the reading comprehension sub- skills test.

To test the second hypothesis "There is a statistically significant difference at the 0.05 level between the mean scores of the experimental group and the control group on the post- administration of the reading comprehension sub- skills test in favor of the experimental one", the independent sample $\mathrm{t}-$ test was used for investigating the difference between the two groups.

Table (2) t- test comparing the two groups' mean scores on each reading comprehension sub skill and their total mean scores on overall the reading comprehension sub- skills on the post administration of the test.

\begin{tabular}{|c|c|c|c|c|c|c|c|}
\hline $\begin{array}{l}\text { Reading } \\
\text { comprehension skills }\end{array}$ & Group & $\mathbf{N}$ & Mean & SD & $\mathbf{T}$ & DF (n1+n2-2) & $\begin{array}{l}\text { Sig. (2- } \\
\text { tailed) }\end{array}$ \\
\hline \multirow{2}{*}{ Scanning } & Control & 33 & 3.33 & 3.189 & \multirow{2}{*}{3.07} & \multirow{20}{*}{64} & \multirow{20}{*}{$\begin{array}{l}\text { Significant } \\
\text { at } 0.05\end{array}$} \\
\hline & Exp. & 33 & 5.78 & 3.212 & & & \\
\hline \multirow{2}{*}{ Skimming } & Control & 33 & 1.879 & 1.9326 & \multirow{2}{*}{4.16} & & \\
\hline & Exp. & 33 & 3.939 & 2.091 & & & \\
\hline \multirow{2}{*}{$\begin{array}{l}\text { Analyzing the written } \\
\text { information }\end{array}$} & Control & 33 & 2.12 & 1.867 & \multirow{2}{*}{4.5} & & \\
\hline & Exp. & 33 & 4.24 & 1.929 & & & \\
\hline \multirow{2}{*}{$\begin{array}{l}\text { Identifying of word } \\
\text { meaning }\end{array}$} & Control & 33 & 2.15 & 1.707 & \multirow{2}{*}{4.6} & & \\
\hline & Exp. & 33 & 4.24 & 2.001 & & & \\
\hline \multirow{2}{*}{ Making inference } & Control & 33 & 0.97 & 1.33 & \multirow{2}{*}{5.1} & & \\
\hline & Exp. & 33 & 2.42 & 0.97 & & & \\
\hline \multirow{2}{*}{$\begin{array}{l}\text { Identifying the relevant } \\
\text { for pronoun }\end{array}$} & Control & 33 & 0.46 & 0.87 & \multirow{2}{*}{7.5} & & \\
\hline & Exp. & 33 & 2.27 & 1.098 & & & \\
\hline \multirow{2}{*}{$\begin{array}{l}\text { Determine the truth of } \\
\text { statement }\end{array}$} & Control & 33 & 1.364 & 1.04 & \multirow{2}{*}{4.8} & & \\
\hline & Exp. & 33 & 2.576 & 1.032 & & & \\
\hline \multirow{2}{*}{ Making Comparison } & Control & 33 & 0.33 & 0.48 & \multirow{2}{*}{7.6} & & \\
\hline & Exp. & 33 & 1.52 & 0.76 & & & \\
\hline \multirow[t]{2}{*}{ Sequencing } & Control & 33 & 0.42 & 0.63 & \multirow{2}{*}{5.01} & & \\
\hline & Exp. & 33 & 1.36 & 0.88 & & & \\
\hline \multirow{2}{*}{$\begin{array}{l}\text { Overall reading } \\
\text { comprehension sub- } \\
\text { skills }\end{array}$} & Control & 33 & 13.03 & 11.75 & \multirow[b]{2}{*}{5.1} & & \\
\hline & Exp. & 33 & 28.33 & 12.79 & & & \\
\hline
\end{tabular}

Table (2) shows that the $\mathrm{t}-$ values which range between (3.07) and (7.6), are statistically significant at the 0.05 level. This indicates that there is a statistically significant difference between the mean scores of the experimental group and the control group in favor of the experimental one. These results validate the second hypothesis. The experimental group outperformed the control group and this may be attributed to the effect of the activities based on IE.
To test the third hypothesis "There is a statistically significant difference at the 0.05 level between the mean scores of the experimental group on the pre administration and the postadministration of the reading comprehension sub -skills test in favor of the post - administration", the correlated sample $\mathrm{t}$ - test was used to investigate the difference between the pre - and the post administration of the reading comprehension sub-skills test.

Table (3) t-test comparing the mean scores of experimental group's on each reading 
comprehension sub- skill and its total mean scores on overall reading comprehension sub-

skills on the pre- and post- administration of the test .

\begin{tabular}{|c|c|c|c|c|c|c|c|}
\hline $\begin{array}{c}\text { Reading } \\
\text { comprehension skills }\end{array}$ & Measurement & $\mathbf{N}$ & Mean & SD & $\mathbf{T}$ & $\begin{array}{r}\text { D. f } \\
(\mathbf{n}-1)\end{array}$ & $\begin{array}{l}\text { Sig. }(2- \\
\text { tailed) }\end{array}$ \\
\hline \multirow{2}{*}{ Scanning } & Pre & 33 & 3.0909 & 2.30981 & \multirow{2}{*}{4.9} & \multirow{20}{*}{32} & \multirow{20}{*}{$\begin{array}{l}\text { Significant } \\
\text { at } 0.05\end{array}$} \\
\hline & Post & 33 & 5.7576 & 3.2116 & & & \\
\hline \multirow{2}{*}{ Skimming } & Pre & 33 & 2.1212 & 1.93258 & \multirow{2}{*}{4.8} & & \\
\hline & Post & 33 & 3.9394 & 2.09074 & & & \\
\hline \multirow{2}{*}{$\begin{array}{l}\text { Analyzing the written } \\
\text { information }\end{array}$} & Pre & 33 & 2.2727 & 1.65874 & \multirow{2}{*}{4.96} & & \\
\hline & Post & 33 & 4.2424 & 1.9289 & & & \\
\hline \multirow{2}{*}{$\begin{array}{l}\text { Identifying of word } \\
\text { meaning }\end{array}$} & Pre & 33 & 2.5758 & 1.91263 & \multirow{2}{*}{4.6} & & \\
\hline & Post & 33 & 4.2424 & 2.00047 & & & \\
\hline \multirow{2}{*}{ Making inference } & Pre & 33 & 0.85 & 1.12142 & \multirow{2}{*}{6.5} & & \\
\hline & Post & 33 & 2.4242 & 0.97 & & & \\
\hline \multirow{2}{*}{$\begin{array}{l}\text { Identifying referent } \\
\text { for pronouns }\end{array}$} & Pre & 33 & 0.3 & 0.68 & \multirow{2}{*}{10.5} & & \\
\hline & Post & 33 & 2.2727 & 1.09752 & & & \\
\hline \multirow{2}{*}{$\begin{array}{c}\text { Determine the truth of } \\
\text { statement }\end{array}$} & Pre & 33 & 1.3636 & 1.06999 & \multirow{2}{*}{5.9} & & \\
\hline & Post & 33 & 2.5758 & 1.03169 & & & \\
\hline \multirow{2}{*}{ Making Comparison } & Pre & 33 & 0.3 & 0.47 & \multirow{2}{*}{8.9} & & \\
\hline & Post & 33 & 1.5152 & 0.76 & & & \\
\hline \multirow[t]{2}{*}{ Sequencing } & Pre & 33 & 0.3 & 0.51 & \multirow{2}{*}{7.2} & & \\
\hline & Post & 33 & 1.3636 & 0.88 & & & \\
\hline \multirow{2}{*}{$\begin{array}{l}\text { Overall reading } \\
\text { comprehension sub- } \\
\text { skills }\end{array}$} & Pre & 33 & 13.1818 & 10.4484 & \multirow[b]{2}{*}{6.6} & & \\
\hline & Post & 33 & 28.3333 & 12.79201 & & & \\
\hline
\end{tabular}

Table (3) shows that the $\mathrm{t}$-values which range between (4.6) and (10.5), are statistically significant at the 0.05 level. This indicates that there is a statistically significant difference between mean scores of the experimental group on pre - and post - administration in favor of the post administration of the reading comprehension sub-skills test. These

results validate the third hypothesis. This indicates that the activities based on IE were effective in enhancing pupils' reading comprehension skills.

\section{The effect size of treatment:}

After estimating the t-values, eta square was used in order to evaluate the effect size of the activities based on IE on the experimental group.

Table (4) Values of $(\eta 2)$ and the effect size of activities based on IE on improving the reading comprehension sub -skills of the experimental group.

\begin{tabular}{|c|c|c|c|c|c|}
\hline $\begin{array}{c}\text { Independent } \\
\text { variable }\end{array}$ & $\begin{array}{c}\text { Reading comprehension } \\
\text { sub skills }\end{array}$ & $\mathbf{T}$ & $\begin{array}{l}\text { D. F (n- } \\
\text { 1) }\end{array}$ & $\begin{array}{l}\text { Value of Eta- } \\
\text { square }(\eta 2)\end{array}$ & $\begin{array}{c}\text { Level of } \\
\text { Effect Size }\end{array}$ \\
\hline \multirow{10}{*}{$\begin{array}{l}\text { The activities } \\
\text { Based on IE }\end{array}$} & Scanning & 4.9 & 32 & 0.43 & \multirow{10}{*}{ High } \\
\hline & Skimming & 4.8 & 32 & 0.42 & \\
\hline & $\begin{array}{l}\text { Analyzing the written } \\
\text { information }\end{array}$ & 4.96 & 32 & 0.44 & \\
\hline & Identifying of word meaning & 4.6 & 32 & 0.40 & \\
\hline & Making inference & 6.5 & 32 & 0.50 & \\
\hline & $\begin{array}{c}\text { Identifying referent for } \\
\text { pronouns }\end{array}$ & 10.5 & 32 & 0.78 & \\
\hline & $\begin{array}{c}\text { Determine the truth of } \\
\text { statement }\end{array}$ & 5.9 & 32 & 0.52 & \\
\hline & Making Comparison & 8.9 & 32 & 0.71 & \\
\hline & Sequencing & 7.2 & 32 & 0.62 & \\
\hline & $\begin{array}{c}\text { Overall reading } \\
\text { comprehension sub skills }\end{array}$ & 6.6 & 32 & 0.58 & \\
\hline
\end{tabular}


Table (4) presents the eta square values $(\eta 2)$ which are between $(0.40)$ to $(0.71)$. The values of $(\eta 2)$ indicate a high effect size of activities based on IE on improving the reading comprehension sub skills of the experimental group.

To test the fourth hypothesis: " There is no a statistically significant difference

Table (5) t-test comparing the two groups' mean scores on each dimension and their total mean scores on overall the dimensions on the pre-administration of the attitude scale.

\begin{tabular}{|c|c|c|c|c|c|c|c|c|}
\hline $\begin{array}{c}\text { Attitude's } \\
\text { dimensions }\end{array}$ & Group & $\mathbf{N}$ & Mean & SD & $\mathbf{T}$ & $\begin{array}{c}\text { DF(n1+ } \\
\text { n2-2) }\end{array}$ & $\begin{array}{l}\text { Level } \\
\text { of Sig. }\end{array}$ & $\begin{array}{l}\text { Sig. (2- } \\
\text { tailed) }\end{array}$ \\
\hline \multirow{2}{*}{$\begin{array}{c}\text { Reasons for } \\
\text { learning English }\end{array}$} & Control & 33 & 12.33 & 4.929 & \multirow{2}{*}{0.15} & \multirow{10}{*}{64} & \multirow{2}{*}{0.13} & \multirow{10}{*}{ Not Sig. } \\
\hline & Exp. & 33 & 10.58 & 4.32 & & & & \\
\hline \multirow{2}{*}{ Way of Teaching } & Control & 33 & 7.3 & 2.823 & & & \multirow{2}{*}{0.82} & \\
\hline & Exp. & 33 & 7.12 & 3.525 & 0.23 & & & \\
\hline \multirow{2}{*}{$\begin{array}{l}\text { Pupil's interest } \\
\text { towards English }\end{array}$} & Control & 33 & 10 & 3.708 & \multirow{2}{*}{0.14} & & \multirow{2}{*}{0.89} & \\
\hline & Exp. & 33 & 10.15 & 5.197 & & & & \\
\hline \multirow{2}{*}{ English as a subject } & Control & 33 & 7.18 & 2.4297 & \multirow{2}{*}{0.22} & & \multirow{2}{*}{0.82} & \\
\hline & Exp. & 33 & 7.36 & 3.999 & & & & \\
\hline \multirow{2}{*}{$\begin{array}{l}\text { overall the attitude } \\
\text { scale dimensions }\end{array}$} & Control & 33 & 36.82 & 12.203 & \multirow{2}{*}{0.44} & & \multirow{2}{*}{0.66} & \\
\hline & Exp. & 33 & 35.21 & 16.874 & & & & \\
\hline
\end{tabular}

Table (5) presents the t-values which range from $(0.15)$, to $(0.44)$. These values are not statistically significant. This indicates that there is no statistically significant difference between the mean scores of the experimental group and the control group. This means that the two groups have the same low level on attitude towards the language. Based on these results, any differences in the post - between the mean scores of the experimental group and the control group on the pre - administration of the attitude scale", the independent sample $\mathrm{t}$ - test was used for comparing the two groups on the pre-administration of the attitude scale. administration can be attributed to the effect of the activities based on IE.

To test the fifth hypothesis "There is a statistically significant difference at the 0.05 level between the mean scores of the experimental group and the control group on the post - administration of the attitude scale in favor of the experimental one", the independent sample t-test was used for investigating the differences between the

\section{two groups.}

Table (6) t-test comparing the two groups' mean scores on each dimension and their mean scores on overall the dimensions on the post- administration of the attitude scale.

\begin{tabular}{|c|c|c|c|c|c|c|c|}
\hline $\begin{array}{l}\text { Attitude's } \\
\text { dimensions }\end{array}$ & Group & $\mathbf{N}$ & Mean & SD & $\mathbf{T}$ & $\begin{array}{c}\text { DF (n1+ } \\
\text { n2-2) }\end{array}$ & $\begin{array}{l}\text { Sig. }(2- \\
\text { tailed })\end{array}$ \\
\hline \multirow{2}{*}{$\begin{array}{c}\text { Reasons for } \\
\text { learning English }\end{array}$} & Control & 33 & 12.7576 & 4.63701 & \multirow{2}{*}{4.5} & \multirow{10}{*}{64} & \multirow{10}{*}{$\begin{array}{l}\text { Significant } \\
\text { at } 0.05\end{array}$} \\
\hline & Exp. & 33 & 17.1515 & 3.20275 & & & \\
\hline \multirow{2}{*}{ Way of Teaching } & Control & 33 & 7.5758 & 2.83979 & \multirow{2}{*}{2.7} & & \\
\hline & Exp. & 33 & 9.4242 & 2.65789 & & & \\
\hline \multirow{2}{*}{$\begin{array}{l}\text { Pupil's interest } \\
\text { towards English }\end{array}$} & Control & 33 & 10.2727 & 3.61657 & \multirow{2}{*}{5.2} & & \\
\hline & Exp. & 33 & 15.5152 & 4.47298 & & & \\
\hline \multirow{2}{*}{ English as a subject } & Control & 33 & 7.4545 & 2.47602 & \multirow{2}{*}{5.4} & & \\
\hline & Exp. & 33 & 11.3333 & 3.26599 & & & \\
\hline \multirow{2}{*}{$\begin{array}{l}\text { Overall the attitude } \\
\text { scale dimensions }\end{array}$} & Control & 33 & 38.0606 & 11.6671 & \multirow{2}{*}{4.99} & & \\
\hline & Exp. & 33 & 53.4242 & 13.27599 & & & \\
\hline
\end{tabular}

Table (6) shows that the t-values which range between (2.7) and (5.4), are statistically significant at the 0.05 level. This indicates that there is a statistically significant difference between the mean scores of the experimental group and the control group in favor of the experimental one. These results validate the fifth 
hypothesis. These results also give a support to the effectiveness of the activities based on IEon improving pupils' attitudes towards English.

To test the sixth hypothesis "There is a statistically significant difference at the 0.05 level between the mean scores of the

Table (7) t-test comparing the experimental group's mean scores on each dimension and its total mean scores on overall the dimensions on the pre- and post - administration of attitude scale.

\begin{tabular}{|c|c|c|c|c|c|c|c|}
\hline $\begin{array}{l}\text { The scale's } \\
\text { dimensions } \\
\end{array}$ & $\begin{array}{c}\text { Measure- } \\
\text { ment }\end{array}$ & $N$ & Mean & $S D$ & $T$ & $\begin{array}{l}\text { D. } f(n- \\
\text { 1) } \\
\end{array}$ & $\begin{array}{l}\text { Sig. (2- } \\
\text { tailed) }\end{array}$ \\
\hline \multirow{2}{*}{$\begin{array}{c}\text { Reasons for } \\
\text { learning English }\end{array}$} & Pre & 33 & 10.5758 & 4.32312 & \multirow{2}{*}{12.7} & \multirow{10}{*}{32} & \multirow{10}{*}{$\begin{array}{l}\text { Significant } \\
\text { at } 0.05\end{array}$} \\
\hline & Post & 33 & 17.1515 & 3.20275 & & & \\
\hline \multirow[t]{2}{*}{ Way of Teaching } & Pre & 33 & 7.1212 & 3.52454 & \multirow{2}{*}{7.2} & & \\
\hline & Post & 33 & 9.4242 & 2.65789 & & & \\
\hline \multirow{2}{*}{$\begin{array}{l}\text { Pupil's interest } \\
\text { towards English }\end{array}$} & Pre & 33 & 10.1515 & 5.19688 & \multirow{2}{*}{8.4} & & \\
\hline & Post & 33 & 15.5152 & 4.47298 & & & \\
\hline \multirow{2}{*}{$\begin{array}{c}\text { English as a } \\
\text { subject }\end{array}$} & Pre & 33 & 7.3636 & 3.99858 & \multirow{2}{*}{7.7} & & \\
\hline & Post & 33 & 11.3333 & 3.26599 & & & \\
\hline \multirow{2}{*}{$\begin{array}{l}\text { Overall the } \\
\text { attitude scale } \\
\text { dimensions }\end{array}$} & Pre & 33 & 35.2121 & 16.87409 & \multirow[b]{2}{*}{9.6} & & \\
\hline & Post & 33 & 53.4242 & 13.27599 & & & \\
\hline
\end{tabular}

Table (7) shows that $\mathrm{t}$ - value which range between (7.2) and (12.7), are statistically significant at the 0.05 level. This indicates that there is a statistically significant difference between the mean scores of the experimental group on the pre - and the post - administration in favor of the post - administration. These results validate the sixth hypothesis. This means

Table (8) :Value of $(\eta 2)$ and the effect size of activities based on IE on improving the attitude of the experimental group.

\begin{tabular}{|c|c|c|c|c|c|}
\hline $\begin{array}{l}\text { Independe } \\
\text { nt variable }\end{array}$ & Dimensions of Attitude scale & $\mathbf{T}$ & $\begin{array}{l}\text { D. F } \\
(\mathbf{n}-1)\end{array}$ & $\begin{array}{l}\text { Value of Eta } \\
\text {-square ( } \eta 2)\end{array}$ & $\begin{array}{c}\text { Level of } \\
\text { Effect Size }\end{array}$ \\
\hline \multirow{5}{*}{$\begin{array}{l}\text { The } \\
\text { activities } \\
\text { Based on IE }\end{array}$} & Reasons for learning English & 12.7 & \multirow{5}{*}{32} & 0.83 & \multirow{5}{*}{ High } \\
\hline & Way of Teaching & 7.2 & & 0.62 & \\
\hline & Pupil's interest towards English & 8.4 & & 0.69 & \\
\hline & English as a subject & 7.7 & & 0.65 & \\
\hline & $\begin{array}{c}\text { Overall the attitude scale } \\
\text { dimensions }\end{array}$ & 9.6 & & 0.74 & \\
\hline
\end{tabular}

Table (8) presents the eta square values ( $\eta 2)$ which range from (0.65) to (0.83).These values indicate a high effect size of activities based on IE on improving the attitude of the experimental group.

\section{Discussion of results}

experimental group on the pre - and the post - administration of the attitude scale in favor of the post - administration", the correlated sample t-test was used for investigating the differences between the pre - and the post - administration of the attitude scale.

that the activities based on IE were effective in modifying pupils' attitude towards the English language.

\section{The Effect Size of treatment}

After estimating the t-values, eta square was used in order to evaluate the effect size of the activities based on IE on the experimental group.

Results revealed that there were significant statistical differences between the two groups favoring the experimental one on the post - administrating of the reading comprehension sub - skills test, and the attitude scale. These differences could be attributed to the effect of the activities based on IE. 
The improvement of pupils' reading comprehension levels and their attitude towards the English language occurred due to the correlation between the reading comprehension skills and IE. Each instrumental of IE has enhanced one or two reading comprehension sub - skills, and paved the way for promoting another reading comprehension sub - skill.

In addition, the way of handling the activities played an effective role in this study. The activities have been applied through the MLE. The activities were arranged, and implemented in a different way than usual. This way attracted pupils' attention and evoked their interests. Pupils who admitted at the beginning that they hada negative attitude towards English, positively modified their attitudes and expressed their pleasure with English lessons. They stated that English became more enjoyable to them than before.

Furthermore, the teacher's tasks changed and became a mediator. The mediator helped pupil learn how to think, and how to learn. This new way of teaching motivated pupils, and encouraged them to participate. This led to improve their reading comprehension skills, and modify their negative attitudes to positive attitudes towards the language.

In addition, the results revealed that there was a correlation between the performance in reading comprehension and attitude towards the language. This result is in line with the results of the study conducted by Momani (2009) which reported that there is a strong correlation between the learners' attitudes toward learning English and their performance in reading comprehension.

The results of this study are in line with those of the studies concerning with the effect of IE like Getz (1992), El-Banna (2000),Shoaer (2003), El-Seady (2008), Qorany (2005), Hela, et al (2008), Abead (2010), and AL-Nifayee (2010).

\section{Recommendations}

In light of the results and conclusion of the study, the following recommendations can be suggested:

1. EFL teachers should not limit themselves to the Teacher Guide or textbook activities; they should adapt the curriculum according to their pupils' needs and interests.

2. IE should be used as a framework for developing reading comprehension skills

3. Adapting IE in teaching other language skills.

4. Searching for new techniques, approaches or programs to develop the pupils' attitudes towards learning EFL, and enhancing reading comprehension skills.

\section{Suggestions for future researches}

It is recommended to:

1. Design activities based on IE for improving other language skills than reading.

2. Test the effect of the activities which were used in the study on improving different language skills.

3. Adapt IE indeveloping the reading comprehension skills of other EFL learners at different stages (e.g. secondary stage or primary stage), or forpupils with special needs (blind and deaf pupils).

4. Design a training program for the teachers on how to implement IE in their teaching.

\section{References}

Al-Ghoul, M. H. (2009).Curricula of Arabic Language and Methods and Styles of TeachingIt.Jordan,Irbid: Dar al-kitab Al-Thaqafi.

AlHmali, J. (2007). Student attitudes in the context of the curriculum in Libyan education in middle and high schools.(Doctoral dissertation), University of Glasgow. Libya. RetrievedApril 24, 2016 from http://t 
AL-Nifayee, A.M. (2010). The Effectiveness of the Instrumental Enrichment Approach on the Enhancement of Reading Comprehension Skills of Preparatory Stage Pupils with English Language Learning Difficulties. (Master Thesis)Faculty Education.TaifUniversity.KSA. Retrieved April 24, 2016fromhttp://files.eric.ed.gov/fullte $\underline{\mathrm{xt} / \mathrm{ED} 514146 . \mathrm{pdf}}$

Al Noursi,O. (2013). Attitude towards Learning English: The case of the UAETechnological High School. International Research Journals,4(1), 21-30. RetrievedApril24,2016Fromhttp:// interesjournals.org/ER/pdf.

Alptekin, C. (2006, December). Cultural familiarity in inferential and literal comprehension in L2 reading. System, 34 (4), 494-508. Retrieved April 24, 2016 fromhttp://www.sciencedirect. com/

science/article/pii/S0346251X060008 32

Ben-Hur, M.\& Sugar, P. (2006). FIEBasic Project.( published report), Alaska State Department of Education: Johns Hopkins University.U. S.Retrieved April 24, $2016 \quad$ fromhttp:// education.jhu.edu/PD/newhorizons/st rategies/topics/Instrumental\%20Enric hment/hur3.htm

Brainin, S. (1982).The effects of Instrumental Enrichment on the reasoning abilities, reading achievement, and task orientation of 6th grade underachievers. (Unpublished doctoral dissertation),Columbia University, USA.

Erten,I. H., \&Karakaş, M. (2007, December). Understanding the divergent influences of reading activities on the comprehension of short stories.The Reading Matrix, 7 (3), 113-133. Retrieved April 24, 2016 from http://www.readingmatrix.com/articl es/erten karakas/article.pdf

Fakeye, D. (2010, January ). Students' Personal Variables as Correlates of Academic Achievement in English as a Second Language in Nigeria.Journal of Social Sciences, 22(3), 205-211. RetrievedApril 24, 2016 fromhttp://www. krepublishers.com/... Journals/...JSS22-3-205-10-775-Fakeye-D-O-

Getz, T (1993) Feuerstein`s instrumental enrichment integrated into a developmental class. Retrieved April 24, 2016 From Pikes peak community college, Colorado web site:http://www.umanitoba.ca/unevoc /conference/papers/getz.pdf

Ghaith, G., \& Obeid, H. (2004, March).Effect of think Alouds on literal and higher-order reading comprehension.Educational

Research Quarterly, 27(3), 49-57. Retrieved April 24, 2016from http://eric.ed.gov/?id=EJ792862

Ghazali, S., Setia, R., Muthusamy, C. \&Jusoff, K. (2009, December).ESL Students' Attitude towards Texts and Teaching Methods Used in Literature Classes.EnglishLanguage Teaching, 2(4), 51-56. RetrievedApril 24, 2016 fromhttp://www.

ccsenet.org/journal/index.php/elt/arti cle/viewFile/4445/3786.

Momani, M. (2009).The Jordanian Secondary Stage students Achievement in Reading Comprehension accordingto their views towards Learning English as a Foreign Language.(Doctoral Dissertation) .Jordan University.Jordan

.RetrievedApril24,2016fromhttps://th eses.ju.edu.jo/default2.aspx 
Rani, Kalluri (2000).Educational Aspirations and Scientific Attitudes, New Delhi :Discovery Publishing House.

Williams, J.R. and Kopp, W.L.(1994). Implementation of Instrumental Enrichment and cognitive modifiability in the Taunton Public Schools: A model for systemic implementation in U.S. Schools. In M. Ben-Hur (Ed.).ON FEUERSTEIN"S INSTRUMENTAL ENRICMENT. Palatine, IL: IRI Skyklight, pp. 261-271

$$
\text { المراجع العربيه }
$$

ابراهيم محمد شعير ( ( . . r، مارس )." فعالية

استخدام استراتيجية الإثراء الوسيليفي تنمية

بعض عمليات العلم والتحصيل الدراسي

لدى التلاميذ المتأخرين دراسيا في مادة

العلوم بالمرحلة الإعدادية" ، ورقة عمل

مقدمةضمن فاعلياتالمؤتمر العلميالسنوي

لكلية التربية جامعة المنصورةالمنعقد في

رحاب كلية التربية جامعة المنصورة،

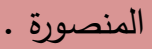

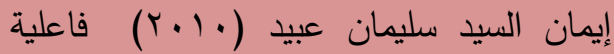

برنامج الإثراء الوسيليفي تتمية بعض

مهارات التفكير والتحصيل الدراسي لدى : لدى

التلاميذ المعاقين سمعياً في مادة العلوم

بالمرحلة الإعدادية المرنية (رسالة

ماجستير غير منشورة ). كلية التربية جامعة المنصورة، المنصورة.

حمدي عبد العظيم البنا ( (... ، ، مايو ) فعاليه الاثراء الوسيلنفى التحصيل وتعديل.

انماط التفضيل المعرفى للتلاميذ المتفوقين
ذوى صعوبات تعلم

بالمرحلهالاعداديه .مجلة كلية التربيه،

العدد ( م乏).

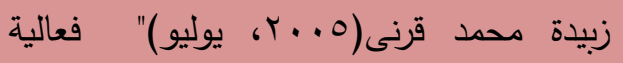

استخدام الاثراء الوسيلى فى تتمية مهارات

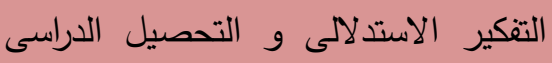

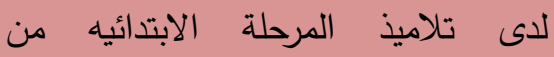

مضطربى الانتباه ذوى النشاط الزائد"،

ورقة عمل مقدمة ضمن فاعليات المؤتمر

العمى التاسع معوقات التربية فى الوطن

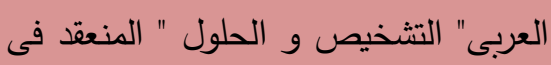

رحاب كلية التربيه جامعة عين شمس ل القاهرة.

عزة محمد عبده حلة. ( (. • (ب، ابريل ).

فاعلية برنامج الإثراء الوسيلي التحصيل وتتمية بعض مهارات التفكير لطالبات المرحلة المتوسطة بمدينة الطائف.مجلة البحث فى التربية وعلم

(1) النفس.r (1)

منصور سمير السيد الصعيدي(1 . . r) فاعلية

استراتيجية الاثراء الوسيلي في تدريس

الرياضيات و اثرها علي تتمية بعض

مهارات التفكير لدي ت تلاميذ المرحلة

الاعدادية.(رسالة ماجستير غير منشورة)

كلية التربيةجامعة بنها، بنها. 